\title{
Layanan Informasi Karir dalam Meningkatkan Kematangan Karir pada Peserta Didik Kelas X di Sekolah Madrasah Aliyah Qudsiyah Kotabumi Lampung Utara Tahun Pelajaran 2016/2017
}

\author{
Badrul Kamil dan Daniati
}

Dosen Fakultas Tarbiyah dan Keguruan, IAIN Raden Intan Lampung

Diterima: 20 April 2016. Disetujui: 17 Juni 2016. Dipublikasikan: Nopember 2016

\begin{abstract}
Abstrak: Kematangan karir peserta didik yang sangat rendah menjadi persoalan dalam dunia pendidikan terlihat dari peserta didik yang masih ragu terhadap karir masa depan dalam menentukan masa depan yang sesuai dengan dirinya. permasalahan dalam penelitian ini adalah "apakah upaya bimbingan karir dalam meningkatkan kematangan Karir Peserta Didik Kelas X Madrasah Aliyah Qudsiyah Kotabumi dapat ditingkatkan setelah melakukan konseling kelompok”. Tujuan penelitian ini adalah untuk mengetahui kematangan karir dapat ditingkatkan dengan menggunakan layanan konseling kelompopada Peserta Didik Kelas X Madrasah Aliyah Kotabumi. Jenis peneltian adalah penelitian kuantitatif dengan metode menggunakan Design One Group Pretest - Posttest. sampel yang digunakan penelitian ini adalah sebanyak 10 peserta didik dari kelas $X$ Madrsah Aliyah Qudsiyah Kotabumi Lmpung Utara hasil dari skor tertinggi penyebaran angket kematangan karir sebanyak 25 item. Angket yang digunakan sebagai Pretest Dan Posttest. Hasil rata-rata skor Kematangan Karir sebelum mengikuti adalah 47,2 dan setelah mengikuti konseling meningkat menjadi 73,3. dari hasil uji $t$ dengan $(d f)=9$ taraf signifikan 0,05 sebesar 2,262. Karena nilai $t_{\text {hitung }} \geq t_{\text {tabel }}(4,063 \geq 2,262)$, maka Ho di tolak dan Ha diterima yang berarti ada pengaruh layanan informasi karir dalam maningkatkan kematangan karir efektif untuk meningkatkan kematangan karir pada peserta didik di madrasah aliyah qudsiyah Kotabumi lampung utara. saran yang di ajukan peneliti yaitu kepada guru bimbingan dan konseling agar dapat melaksanakan pelayanan bimbingan dan konseling dengan menyertakan layanan informasi pada peserta didik. Kata kunci : Layanan Informasi Karir Dalam Meningkatkan Kematangan Karir
\end{abstract}

\section{Pendahuluan}

Masalah karir merupakan salah satu jenis permasalah yang sering dijumpai pada pesrta didik. beberapa pertanyaan yang sering muncul, seperti bagaimana menyiapkan diri untuk masa depan, jenis pendidikan apa yang harus ditempuh untuk mencapai pekerjaan atau karir yang diinginkan, serta bagaimana cara untuk mencapai karir atau pekerjaan tersebut. sejumlah pertanyaan ini menjadi permasalahan yang merisaukan peserta didik. keadaan tersebut merupakan kesulitan-kesulitan yang dialami oleh peserta didik remaja dalam membuat perencanaan karirnya. kesulitan-kesulitan tersebut dapat pula disebabkan karena kurangnya informasi yang dimiliki seperti persyaratan yang dibutuhkan serta minat profesional yang berhubungan dengan pilihan karirnya. Menghadapi situasi atau permasalahan tentang karir tersebut, guru pembimbing harus mampu memilih strategi layanan yang dapat mengajak peserta didik untuk berpartisipasi secara aktif dalam menghadapi permasalahan peserta didik, sehingga peserta didik terlibat secara langsung dalam memecahkan permasalahan yang dihadapinya. sehingga keberadaan bimbingan dan konseling pada sebuah lembaga pendidikan sangat tepat untuk membantu peserta didik dalam menghadapi permasalahan peserta didik.

Selain itu peneliti juga melakukan wawancara dengan peserta didik MA Qudsiyah tentang rencana masa depan mereka menjawab bahwa setelah menyelesaikan pendidikan di MA Qudsiyah kami masih belum tahu cara pasti hendak melanjutkan ke perguruan tinggi atau bekerja, kami masih merasabingung jika ditanya tentang hal tersebut, hal ini disebabkan karena kami belum memikirkannya

Hasil wawancara yang dilakukan peneliti dengan guru bimbingan dan konseling menunjukkan fakta yang serupa. guru bimbingan dan konseling MA Qudsiyah Kotabumi cenderung akan memikirkan kelanjutan studi mereka katika berada di kelas X. mereka belum 
memikirkan mengeni keputusan studi lanjut yang akan mereka ambil lebih awal, sehingga hanya sedikit waktu yang dapat peserta didik gunakan untuk benar-benar memikirkan masa depan mereka.

Hal diatas membuktikan betapa pentingnya kematangan karir. pilihan karir dan langkah-langkah pendidikan dan pelatihan yang tepat akan mengantarkan sesorang menjadi individu yang mempunyai daya saing dalam memperoleh pekerjaan. sebaliknya, rendahnya kematangan karir dapat menyebabkan kesalahn dalam mengambil keputusan karir, termasuk kesalahan dalam menentukan pendidikan lanjutan.

Permasalahan mengenai kematangan karir yang ditemui di MA Qudsiyah cukup beragam. hasil wawancara dengan guru pembimbing, menunjukkan bahwa potensi bimbingan dan konseling di MA Qudsiyah kotabumi perlu ditingkatkan. keterbatasan yang muncul antara lain: peserta didik belum mampu membuat perencanaan karir, mengekplorasi karir, menyusun realisasi keputusan karir. peserta didik yang peneliti temui juga menyampaikan masih kesulitan mengenai tiga hal tersebut. hal ini guru pembimbing belum secara maksimal dalam menyampaikan materi bimbingan.

Penyelesaian tugas-tugas perkembangan yang sesuai pada masing- masing tahapan merupakan indikasi bahwa remaja tersebut telah memiliki kematangan karir. kematangan karir merupakan kesiapan individu untuk membuat keputusan karir dan kesiapanindividu membuat pilihan yang tepat. dalam kematangan karir ini, individu harus dapat memilih karir dan memikirkan berbagai alternatif pekerjaan tetapi belum mengambil keputusan yang mengingat. individu yang memiliki kematangan karir akan membuat keputusan dalam pemilihan karirnya dengan mempertimbangakn nilai- nilai kehidupan, intelegensi, minat, bakat, sifat, kepribadian, keadaan fisik, serta pengetahuan yang dimilikinya dan juga pengaruh dari masyarakat, pendidikan sekolah serta pergaulan teman sebaya, sehingga remaja dapat memutuskan pilihan karirnya dengan baik.

Berdasarkan beberapa fakta yang telah dipaparkan diatas menunjukkan bahwa peserta didik memiliki permasalahan dalam kematangan karir yaitu belum dapat mempersiapkan dan merencanakan karir mereka dengan baik. permasalahan kematangan karir dapat menyebabkan kesalahan mengambil keputusan karir bagi peserta didik di MA. pada kenyataannya, terdapat peserta didik $\mathrm{Ma}$ yang memilih suatu jurusan pendidikan tanpa mempertimbangkan kemampuan, bakat, minat, dan kepribadian. mereka cenderung mengikuti pilihan orang tua, teman, dengan dasar popularitas pekerjaan atau identitas pekerjaan yang disarankan orang tua. individu yang tidak memiliki kematangan karir dapat mengakibatkan kerugian waktu, finansial, dan kegagalan belajar dapat terjadi, ini dikarenakan mereka tidak termotivasi untuk belajar. kematangan karir merupakan salah satu tugas perkembangan yang penting bagi remaja atau dapat mempengaruhi keseluruhan masa depan seseorang, maka apabila remaja berhasil menyelesaikan tugas perkembangan dapat membuatnya bahagia serta sebaliknya apabila seseorang gagal, hal ini dapat membuat tidak bahagia, timbul penolakan dari masyarakat, serta remaja kurang dapat menyesuaikan diri karena cenderung menolak diri atas kegagalan yang dialami.

Permasalahan mengenai kematangan karir yang ditemui di MA kelas X cukup beragam. hasil wawancara terhadap beberapa peserta didik kelas $\mathrm{X}$ ditemukan sejumlah permasalahn kematangan karir yang dialami mereka dianataranya yaitu : belum memiliki pengetahuan dan pemahaman yang akurat tentang potensi diri sendiri yang dapat mendukung karirnya di masa depan, program studi yang dimasuki bukan pilihan sendiri, belum memiliki pemahaman yang mantap tentang kelanjutan studi setelah lulus,belum memahami jenis pekerjaan yang cocok dengan kemampuan sendiri, masih bingung untuk memilih kelanjutan studi dan jenis pekerjaan yang sesuai dengan minat atau kemampuan, dan merasa pesimis bahwa setelah lulus akan melanjutkan studi sesuai dengan yang diharapkan. 
Kematangan karir merupakan gambaran sikap dan kompetensi yang dimiliki peserta didik dalam menentukan pilihan karirnya. peserta didik yang memiliki kematangan karir yang tinggi akan mampu mengambil keputusan pilihan karirnya. sedangkan peserta didik yang tidak mempunyai kematangan karir akan mengalami kesulitan dalm menentukan pilihan karir kedepannya. dengan kematangan karir peserta didik mampu merencanakan masa depannya dengan baik serta akan berdampak pada kebahagiaan hidup.

Penyebab rendahnya kematangan karir peserta didik yang ditunjukkan dengan rendahnyapeserta didik yang merencanakan karir, rendahnya peserta didik yang mencari informasi karir, kurangnya pengetahuan tentang membut keputusan karir, kurangnya pengetahuan tentang dunia kerja, kurangnya pengetahuan tentang kelompok pekerjaan yang lebih disukai dan rendahnya realisasi keputusan Karir peserta didik. padahal kematangan karir merupakan kompetensi inti yang harus dimiliki oleh peserta didik. Richard menyatakan "kematangan karir merupakan refleksi dari proses perkembangan karir individu untuk meningkatkan kapasitas membuat keputusan karir."

Melihat fenomena yang terjadi diatas dibutuhkan suatu pengembangan model dalam layanan bimbingan dan konseling, khususnya layanan bimbingan kelompok untuk meningkatkan kematangan karir peserta didik di MA Qudsiyah kotabumi. dihrapkan peserta didik mampumerencanakan pilihan karir, mengetahui tentang kelompok pekerjaan yang disukai dan keterampilan untuk menentukan pilihan karir dan mampu mengeksplorasi karir serta realisasi keputusan karir. salah satu upaya untuk meningkatkan kematangan karir dapat dilakukan melalui layanan bimbingan kelompok.

Layanan informasi merupakan kegiatan memberikan pemahaman kepada individuindividu yang berkepentingan tentang berbagai hal yang diperlukan untuk menjalani suatu tugas atau kegiatan, atau untuk menentukan arah suatu tujuan atau rencana yang dikehendaki. Dengan demikian, layanan informasi itu pertama- tama merupakan perwujudan dari fungsi pemahaman dalam bimbingan dan konseling.

Penyajian informasi dalam rangka program bimbingan ialah kegiatan membantu siswa dalam mengenali lingkungannya, terutama tentang kesempatan-kesempatan yang ada didalamnya, yang dapat dimanfaatkan siswa baik untuk masa kini maupun masa yang akan datang Penyajian informasi itu dimaksudkan untuk memberikan wawasan kepada para siswa sehingga ia dapat menggunakan informasi itu baik untuk mencegah atau mengatasi kesulitan yang dihadapinya, serta untuk merencanakan masa depan. Perencanaan kehidupan ini mencakup, kehidupan dalam studinya, dalam pekerjaannya, maupun dalam membina keluarga.

Layanan informasi juga merupakan usaha untuk membekali para siswa dengan pengetahuan tentang data dan fakta dibidang pendidikan sekolah, bidang pekerjaan dan bidang perkembangan pribadi-sosial, supaya mereka dengan belajar tentang lingkungan hidupnya lebih mampu mengatur dan merencanakan kehidupannya sendiri. Program bimbingan yang tidak memberikan layanan pemberian informasi akan menghalangi peserta didik untuk berkembang lebih jauh, karena mereka membutuhkan kesempatan untuk mempelajari data dan fakta yang dapat mempengaruhi jalan hidupnya. Namun, mengingat luasnya informasi yang tersedia dewasa ini, mereka harus mengetahui pula informasi manakah yang relevan untuk mereka dan mana yang tidak relevan, serta informasi macam apa yang menyangkut data dan fakta yang tidak berubah dan yang dapat berubah dengan beredarnya roda waktu.

Dari beberapa pengertian tentang layanan informasi diatas dapat diambil kesimpulan bahwa layanan informasi adalah suatu kegiatan atau usaha untuk membekali para siswa tentang berbagai macam pengetahuan supaya mereka mampu mengambil keputusan secara tepat dalam kehidupannya.

Tujuan layanan informasi ada dua macam yaitu secara umum dan khusus. Secara umum agar terkuasainya informasi tertentu sedangkan secara khusus terkait dengan fungsi pemahaman (paham terhadap informasi yang diberikan) dan memanfaatkan informasi dalam 
penyelesaian masalahnya. Layanan informasi menjadikan individu mandiri yaitu memahami dan menerima diri dan lingkungan secara positif, objektif dan dinamis, mampu mengambil keputusan, mampu mengarahkan diri sesuai dengan kebutuhannya tersebut dan akhirnya dapat mengaktualisasikan dirinya. Adapun tujuan yang ingin dicapai dengan penyajian informasi adalah sebagai berikut:

a. para siswa dapat mengorientasikan dirinya kepada informasi yang diperolehnya terutama untuk kehidupannya, baik semasa masih sekolah maupun setelah menamatkan sekolah;

b. para siswa mengetahui sumber-sumber informasi yang diperlukan;

c. para siswa dapat menggunakan kegiatan kelompok sebagai sarana memperoleh informasi; dan

d. para siswa dapat memilih dengan tepat kesempatan-kesempatan yang ada dalam lingkungannya sesuai dengan minat dan kemampuanya.

Berdasarkan uraian di atas dapat disimpulkan bahwa tujuan layanan informasi adalah supaya para siswa memperoleh informasi yang relevan dalam rangka memilih dan mengambil keputusan secara tepat guna pencapaian pengembangan diri secara optimal. Dalam penelitian ini tujuan dari layanan informasi adalah membekali siswa dengan berbagai informasi tentang potensi diri sehingga siswa mampu meningkatkan pemahaman potensi diri guna mencapai kualitas hidup yang lebih baik.

Menurut Hasan Kematangan adalah kematangan jiwa seseorang dalam proses perkembangan ke arah kedewasaan. Kematangan karir merupakan aspek yang perlu dimiliki siswa untuk jenjang karir dimasa depan, hal tersebut terjadi karena dengan adanya kematangan karir yang dimulai sejak dini maka sedikit banyak telah ambil bagian dalam mempersiapkan karir masa mendatang. Berdasarkan penjelasan di atas dapat di simpulkan bahwa kematangan karir adalah proses perkembangan ke arah kedewasaan hal ini perlu dimiliki siswa untuk jenjang karir yang dimulai sejak dini. Menurut Crites mendefinisikan kematangan karir merupakan kemampuan individu untuk membuat pilihan karir, yang meliputi penentuan keputusan karir, pilihan yang realistik dan konsisten. Berdasarkan penjelasan di atas dapat disimpulkan bahwa kematangan karir adalah kemampuan seseorang dalam memilih karir

Super berpendapat bahwa keberhasilan dan kesiapan remaja untuk memenuhi tugastugas terorganisir yang terdapat dalam setiap tahapan perkembangan karir adalah definisi dari kematangan karir. Berdasarkan penjelsan diatas dapat disimpulkan bahwa kematangan karir menurut super keberhasilan dan kematangan peserta didik yang telah matang dalam merencanakan karir.

Dari beberapa pendapat tersebut, dapat disimpulkan bahwa kematangan karir adalah kemampuan individu untuk membuat pilihan karir dalam proses menuju kedewasaan sebagai bekal pada karir masa mendatang. Kematangan karir juga merupakan hubungan antara usia individu dengan tugas-tugas dan peranan yang sesuai dengan tahap perkembangan.

Menurut Super kematangan karir terdiri dari:

a. Perencanaan Karir (Career Planning)

Dimensi ini mengukur tingkat perencanaan melalui sikap terhadap masa depan. Individu memiliki kepercayaan diri, kemampuan untuk dapat belajar dari pengalaman, menyadari bahwa dirinya harus membuat pilihan pendidikan dan pekerjaan, serta mempersiapkan diri untuk membuat pilihan tersebut. Nilai rendah pada dimensi careerplanning menunjukkan bahwa individu tidak merencanakan masa depan di dunia kerja dan merasa tidak perlu untuk memperkenalkan diri atau berhubungan dengan pekerjaan. Nilai tinggi pada dimensi career planning menunjukkan bahwa individu ikut berpartisipasi dalam aktivitas perencanaan karir yaitu belajar tentang informasi karir, berbicara dengan orang dewasa tentang rencana karir, mengikuti kursus dan pelatihan yang akan membantu dalam menentukan karir, berpartisipasi dalam kegiatan ekstrakulikuler dan bekerja paruh waktu 
b. Eksplorasi Karir (Career Exploration)

Dimensi ini mengukur sikap terhadap sumber informasi. Individu berusaha untuk memperoleh informasi mengenai dunia kerja serta menggunakan kesempatan dan sumber informasi yang berpotensial seperti orangtua, teman, guru, dan konselor. Nilai rendah pada dimensi career exploration menunjukkan bahwa individu tidak perduli dengan informasi tentang bidang dan tingkat pekerjaan.

c. Pengetahuan Tentang Membuat Keputusan Karir (Career Decision Making)

Dimensi ini mengukur pengetahuan tentang prinsip dan cara pengambilan keputusan. Individu memiliki kemandirian, membuat pilihan pekerjaan yang sesuai dengan minat dan kemampuan, kemampuan untuk menggunakan metode dan prinsip pengambilan keputusan untuk menyelesaikan masalah termasuk memilih pendidikan dan pekerjaan. Nilai rendah pada dimensi career decisionmaking menunjukkan bahwa individu tidak tahu apa yang harus dipertimbangkan dalam membuat pilihan. Hal ini berarti individu tidak siap untuk menggunakan informasi pekerjaan yang telah diperoleh untuk merencanakan karir. Nilai tinggi pada dimensi career decision making menunjukkan bahwa individu siap mengambil keputusan.

d. Pengatahuan Tentang Dunia Kerja (World Of Word Information)

Dimensi ini mengukur pengetahuan tentang jenis-jenis pekerjaan, cara untuk memperoleh dan sukses dalam pekerjaan serta peran-peran dalam dunia pekerjaan. Nilai rendah pada dimensi worldof work information menunjukkan bahwa individu perlu untuk belajar tentang jenis-jenis pekerjaan dan tugas perkembangan karir. Individu kurang mengetahui tentang pekerjaan yang sesuai dengannya. Nilai tinggi pada dimensi world of work information menunjukkan bahwa individu dengan wawasan yang luas dapat menggunakan informasi pekerjaan untuk diri sendiri dan mulai menetapkan bidang serta tingkat pekerjaan.

e. Pengetahuan Tentang Kelompok Pekerjaan Yang Lebih Disukai (Knowledge of Preferred Occupational Group)

Dalam aspek ini adalah siswa diberi kesempatan untuk memilih satu dari beberapa pilihan pekerjaan, dan kemudian ditanyai mengenai hal- hal yang berkaitan dengan pekerjaan tersebut. Mengenai persyaratan, tugas- tugas, faktor-faktor dan alasan yang mempengaruhi pilihan pekerjaan dan mengetahui resiko-resiko dari pekerjaan yang dipilihnya. Indikator pada aspek ini adalah pemahaman mengenai tugas dari pekerjaan yang diinginkan, memahami persyaratan dari pekerjaan yang diinginkan, mengetahui faktor dan alasan yang mempengaruhi pilihan pekerjaan yang diminati dan mampu mengidentifikasi resiko-resiko yang mungkin muncul dari pekerjaan yang diminati

f. Realisasi Keputusan Karir (Realisation)

Realisasi keputusan karir adalah perbandingan antara kemampuan individu dengan pilihan karir pekerjaan secara realistis. Aspek ini antara lain: memiliki pemahaman yang baik tentang kekuatan dan kelemahan diri berhubungan dengan pekerjaan yang diinginkan, mampu melihat faktor-faktor yang mendukung dan menghambat karir yang diinginkan, mampu mengambil manfaat membuat keputusan karir yang realistic.

Kesimpulan dari beberapa pendapat tersebut yaitu kematangan karir memiliki dimensidimensi atau faktor yang mempengaruhinya antara lain perencanaan karir, eksplorasi karir, pengetahuan tentang pembuatan keputusan karir, informasi mengenai dunia kerja, pengatahuan kelompok pekerjaan yang lebih disukai dan realisasi keputusan karir.

Pelayanan konseling kelompokyaitu layanan bimbingan dan konseling yang memungkinkan peserta didik memperoleh kesempatan untuk membahas dan mengetaskan permasalahan yang dialaminya melalui dinamika kelompok. dinamika kelompok adalah suasana yang hidup, yang berdenyut, yang bergerak, yang berkembang yang ditandai dengan 
adanya interaksi antarsesama anggota kelompok. pelayanan konseling kelompok merupakan pelayanan konseling yangdiselenggarakan dalam suasana kelompok.

Tujuan konseling kelompok:

a. melatih anggota kelompok agar berani berbicara dengan orang banyak,

b. Melatih anggota kelompok dapat bertanggung jawab rasa terhadap teman sebayanya,

c. Dapat mengembangkan bakat dan minat masing-masing anggota kelompok,

d. Mengetaskan permasalahan- permasalahan kelompok,

Proses Pelaksanaan Konseling Kelompok dilaksanakan melalui tahap-tahap:

a. Tahap Pembentukan yaitu tahapan untuk membentuk kerumunan sejumlah individu menjadi satu kelompok yang siap mengembangkan dinamika kelompok dalam mencapai tujuan bersama.

b. Tahap Peralihan yaitu tahap untuk mengalihkan kegiatan awal kelompok ke kegiatan berikutnya yang lebih terarah pada pencarian tujuan kelompok.

c. Tahap Pengakhiran yaitu tahapan akhiran kegiatan untuk melihat kembali apa yang sudah dilakukan dan dicapai oleh kelompok serta merencanakan kagiatan selanjutnya.

\section{Metode Penelitian}

Penelitian skripsi ini penulis menggunakan metode pendekatan penelitian secara kuantitatif. Metode kuantitatif adalah metode penelitian yang dapat diartikan sebagai metode penelitian yang berlandaskan pada filsafat positivisme, digunakan untuk meneliti pada populasi atau sampel tertentu, pengumpulan data menggunakan instrumen penelitian, analisis data tertentu, pengumpulan data menggunakan instrumen penelitian, analisis data bersifat kuantitatif atau statistik, dengan tujuan untuk menguji hipotesis yang telah ditetapkan.

Berdasarkan pendapat tersebut, maka yang dimaksud dengan metode penelitian adalah suatu ilmu pengetahuan yang membahas tentang cara-cara yang digunakan dalam mengadakan penelitian yang berfungsi sebagai panduan atau cara yang dilakukan untuk mendapatkan informasi data secara akurat. Penelitian ini dilakukan di Madrasah Aliyah Qudsiyah Lampung Utara dengan melihat hal-hal yang berkaitan dengan masalah yang diteliti, sehingga diakhir penelitian akan diperoleh gambaran umum yang baik tentang hal tersebut.

\section{Hasil dan Pembahasan}

Penelitian ini dilaksanakan di Madrasah Aliyah Qudsiyah Lampung Utara Tahun Pelajaran 2016-2017 pada bulan September 2016. Hasil penelitian diperoleh melalui penyebaran instrumen yang bertujuan untuk memperoleh data mengenai gambaran kematangan karir peserta didik dan sekaligus sebagai dasar penyesuaian isi layanan informasi dalam meningkatkan kematangan karir peserta didik. Hasil penyebaran instrument dijadikan analisis awal untuk perumusan layanan informasi dalam meningkatkan kematangan karir peserta didik.

Populasi dalam penelitian ini adalah peserta didik kelas VIII SMP Negeri 7 Bandar Lampung yang berjumlah 35 peserta didik. Sedangkan sampel dalam penelitian ini berjumlah 10 peserta didik yang mengalami kematangan karir yang rendah.

Penelitian ini bertujuan meningkatkan kematangan karir peserta didik di Madrasah Aliyah Qudsiyah Kotabumi Lampung Utara yang memiliki kategori yang rendah. Peneliti dalam menangani permasalahan kematangan karir yang rendah menggunakan layanan informasi karir dalam meningkatkan kematangan karir.dalam pelaksanaan layanan informasi peneliti menggunakan beberapa sampel peserta didik kelas $X$ dan peserta didik mengikuti layanan informasi karir. Pengambilan sampel ini berdasarkan hasil angket yang diberikan kepada peserta didik dari hasil angket yang memiliki kematangan karir yang rendah 4 peserta didik dan yang sangat rendah 6 peserta didik adapun hasil penyebaran angket dapat dilihat pada Tabel 
Tabel 7 Hasil penyebaran angket awal (Pre-Test) peserta didik kelas X Madrasah Aliyah Qudsiyah Kotabumi Lampung Utara.

\begin{tabular}{|c|c|c|c|}
\hline Kategori & Rentan g Skor & $\sum$ & Presentase \\
\hline Sangat Tinggi & $75-92$ & 0 & $0 \%$ \\
\hline Tinggi & $57-74$ & 0 & $0 \%$ \\
\hline Rendah & $39-56$ & 4 & $40 \%$ \\
\hline SangatRendah & $21-38$ & 6 & $60 \%$ \\
\hline & & 10 & $100 \%$ \\
\hline
\end{tabular}

Berdasarkan Tabel berikut terlihat bahwa kematangan karir peserta didik tergolong rendah, sehingga peneliti akan memberikan layanan informasi karir untuk meningkatkan kematangan karir peserta didik, Layanan yang akan diberikan yaitu layanan informasi.

Penelitian ini dilakukan pada tanggal 1 september 2016 di MAQ di kotabumi lampung utara, sedkripdi proses pelaksanaan penelitian konseling kelompok dilakukan dengan memaparkan hasil pengamatan selama proses penelitian. Kemudian hasil pengamatan yang telah dilakukan selama proses penelitian. Kemudian hasil pengamatan yang dilakukan yang telah dilakukan selama proses penelitian akan dijelaskan sebagai berikut :

1) Pertemuan pertama

Pada pertemuaan ini peneliti memberikan angket awal (pre-test). Dilakukan pada tanggal 2 september 2016 dengan tujuan untuk mengetahui gambaran kondisi awal peserta didik tentang kematangan karir peserta didik yang rendah dengan menberikan penjelasan tentang peserta didik yang di katakan matang rencana karirnya atai tidak dengan memberikan pengertian tentang perencanaan karir. Perencanaan karir Aspek perencanaan karir merupakan aktivitas pencarian informasi dan seberapa besar keterlibatan individu dalam proses tersebut. kondisi tersebut didukung oleh pengetahuan tentang macam-macam unsur pada setiap pekerjaan. indikator ini adalah menyadari wawasan dan persiapan karir, memahami pertimbangan alternatif pilihan karir dan memiliki perencanaan karir dimasa depan. Peserta didik berantusias mengikuti pelaksaan prettest. setelah peneliti mendapatkan data dari hasil prettest peneliti kemudian menentukantreatment yang akan diberikan kepada peserta didik yang tergolong kematangan karir peserta didik yang rendah. Maka kematangan karir yang tinggi harus segera diatasi, untuk mengatasinya peneliti menggunakan layanan konseling kelompok dengan layanan informasi di kelas konseling kelompok tersebut.

2) Pertemuan kedua

Pada pertemuan kedua peneliti membahas tentang Explorasi karir Merupakan individu untuk melakukan pencarian informasi karir dari berbagai sumber karir, seperti kepada orang tua, saudara, kerabat, teman, guru bidang studi, konselor dan sebagainya. aspek ekspolasi karir berhubungan dengan seberapa banyak informasi yang diperoleh peserta didik dari berbagai sumbertersebut. indikator dari aspek ini adalah mengumpulkan informasi karir dari berbagai sumber dan memanfaatkan informasi karir yang telah diperoleh dan pada hari itu juga konseling kelompok dengan pendekatan behavioral diawali dengan opening seperti menyambut peserta didik dengan baik, mengucap salam, pembicaraan dengan menanyakan kabar dan memperkenalkan diri serta tidak lupa juga membina hubungan dengan baik dengan peserta didik. Tujuanya adalah agar peserta didik merasa aman, nyaman, dan percaya dengan peneliti, sehingga peserta didik dapat hadir dengan sukarela, sebelumnya peneliti mengucapkan terimakasih kepada peserta didik yang sudah berpartisipasi dan bergabung dalam konseling kelompok ini.

Setelah suasana kondusif, peneliti mulai menanyakan tentang kesiapan anggota kelompok untuk melaksanakan konseling kelompok. Setelah itu peneliti melaksanakan kegiatan 
pengakraban. Pengakraban dilaksanakan untuk mengikuti kegiatan konseling kelompok, sehingga peserta didik terlihat rileks dan tidak tegang. Pengakraban dimantapkan dengan permainan "rangkaian nama", yaitu merangkaian nama panggilan teman sekolahnya. Selanjutnya pemimpin kelompok mempersilahkan anggota untuk mengungkapkan permasalahnya. Dalam tahap ini seluruh peserta didik berperan aktif dan terbuka mengemukakan apa yang dirasakan, dipikirkan dan dialaminya. Selanjutnya memilih masalah yang sering muncul sesuai kesepakatan anggota kelompok. Setelah itu dilanjutkan dengan mengeluarkan pendapat, saran atau gagasan. Setelah permasalahan tersebut mendapakan solusi dan saran maka kegiatan ini akan diakhiri. Pemimpin kelompok meminta beberapa orang anggota kelompok untuk menyimpulkan hasil yang diperoleh dalam konseling kelompok dengan mengungkapkan kesan- kesanya. Mengingat waktu tidak memungkinkan lagi maka pemimpin kelompok menjelaska pertemuan selanjutnya dan mengakhiri pertemuan dengan membaca alhamdulillah.

3) Pertemuan ketiga

Pada pertemuan ketiga ini adalah pertemuan kedua melaksanakan layanan konseling kelompok pendekatan behavioral dengan teknik modeling. Konseling dilakukan pada hari jum'at tanggal 9 september 2016 yang berdurasi 45 menit, seperti pertemuan sebelumnya proses konseling kelompok diawali dengan opening seperti menyambut peserta didik dengan baik, mengucap salam, pembicaraan dengan menanyakan kabar dan memperkenalkan diri serta tidak lupa juga membina hubungan baik dengan peserta didik. Tujuanya adalah agar peserta didik aman dan nyaman. Pengetahuan tentang membuat keputusan karir Merupakan kemampuan peserta didik dalam manggunakan pengetahuan dan pemikiran dalam membuat perencanaan karir. konsep ini didasari pada tuntutan peserta didik untuk membuat keputusan karir. dengan asumsi apabila peserta didik mengatahui bagaimana orang lain membuat keputusan karir maka diharapkan mereka juga mampu membuat keputusan karir yang tepat bagi dirinya. Selain itu para anggota mengungkapkan gagasan, ide dan saranya. Untuk mengakhiri pertemuan konseling pada hari ini, peneliti tidak lupa menanyakan pemahaman apa yang sudah diperoleh selama kegiatan kepada peserta didik. Sebelumnya melanjutkan pertemuan selanjutnya peneliti akan mengamati peserta didik yang mempunyai permasalahan perilaku agresif dikelas berlangsung. Peneliti ingin melihat menurunya perilaku agresif peserta didik tersebut.

4) Pertemuan keempat

Pada pertemuan keempat ini adalah pelaksanaan konseling kelompok dengan memberikan informasi. Sebelum dilaksanakan layanan konseling ketiga ini peneliti mengamati perubahan perilaku peserta didik setelah diadakan 2 kali pertemuan layanan konseling. Konseling dilakukan pada hari Hari senin pada tanggal 5 dan hari jum'at tanggal 9 september 2016 yang berdurasi 45 menit. Pada pertemuan ini seperti biasa proses konseling diawalin dengan peneliti melakukan opening dengan menyambut peserta didik dengan baik, memberi salam, menyapa dan menanyakan kabar dan perkembangan peserta didik, serta menggunakan kalimat yang membuat konseli nyaman dan tidak tegang saat melaksanakan proses konseling untuk memasuki pembahasan inti. Sebelum memasuki kegiatan inti pada pertemuan ini peneliti mengajak peserta didik untuk melakukan permainann. Setelah peserta didik merasa nyaman maka akan dimulainya kegiatan inti. Pada kegiatan pertemuan ketiga ini anggota kelompok meminta peserta didiknya. Pemimpin kelompok meminta anggota untuk mengungkapkan gagasan, ide, pendapat dan saranya. sebelum pertemuan ketiga dilaksanakan pemimpin kelompok mengamati perubahanya waktu kegiatan konseling tersebut adanya masih ada peserta didik yang melakukan Pengetahuan informasi tentang dunia kerja Aspek ini terdiri dari dua komponen, yakni terkait dengan tugas perkembangan, yaitu individu harus tau minat dan kemampuann diri, mengatahui cara orang lain mempelajari hal-hal yang berkaitan dengan pekerjaan dan 
mengatahui alasan orang berganti pekerjaan. komponen kedua adalah mengetahui tugastugas pekerjaan dalam suatu jabatan dan perilaku-perilaku dalam bekerja. Pada saat kegiatan inti sudah terlihat peserta didik yang aktfi dalam mengungkapkan ide dan pendapatnya. Mengingat waktunya akan diakhri pemimpi kelompok untuk menjelaskan hasil yang di peroleh pada proses konseling kelompok pendektan behavioral dengan teknik modeling, serta mempersilahkan untuk mengungkapkan kesan-kesanya. Sebelum akan dilanjutkan ke pertemaun ke empat peneliti kembali akan mengamati perubahan perilaku peserta didik.

5) Pertemuan kelima

Pertemuan kelima adalah pelaksanaan konseling kelompok yang terahir. Sebelum pertemuan ini dilaksanakan peneliti sudah mengamati perubahan perilaku peserta didik pada saat konseling berlangsung. Pertemuan dilaksanakan pada hari jum'at tanggal 16 september 2016 yang berdurasi 60 menit, pada pertemuan ini seperti biasa proses konseling diawali dengan peneliti melakukan opening dengan menyambut peserta didik dengan baik, memberikan salam, menyapa, menanyakan kabar dan perkembangan konseli serta menggunakan kalimat yang membuat peserta didik nyaman dan tidak tegang saat melaksankan proses konseling untuk memasuki pembahasan inti. Pemimpin kelompok dan anggota kelompok bersepakat untuk mengulas pembahasan yang telah dilaksanakan pada proses koseling sebelumnya. Karena secara garis besar permasalahan yang sedang di bahas adalah permasalahan yang dibahas adalahkematangan karir. Dalam pertemuan ini sudah terlihat adanya perubahan perilaku peserta didik. Peserta didik sudah menampilkan perilaku barunya, kemudian pemimpin kelompok memberikan penguatan positif dengan cara memberikan pujian kepada peserta didik tersebut. Namun pemberian pujian tidak boleh berlebihan, setelah itu peneliti mengevaluasi kegiatan konseling kelompok dari pertama sampai terahir. Peneliti mengevaluasi kegiatan konseling kelompok yang telah dilaksanakan dari pertemuan pertama dan terahir. Peneliti juga memberikan kesempatan kepada peserta didik untuk mengevaluasi hal yang sudah dilakukan oleh peserta didik setelah diberi treatment dan menanyakan tentang hal-hal yang sudah dilakukan oleh peserta didik serta hambatan apa saja yang dihadapi. Peneliti menyimpulkan semua yang dilakukan dan diungkapkan peserta didik selama mengikuti kegiatan ini. Sebelum kegiatan ini diakhiri peneliti meminta maaf kepada peserta didik apabila selama melaksanakan konseling kelompok dari pertama sampai akhir terdapat kesalahan. Tidak lupa juga mengucapkan terima kasih kepada peserta didik karena sudah berkenaan dan berpartisipasi hadir dalam pelaksanaan layanan konseling kelompok dari awal hingga akhir. Peneliti menanyakan pemahaman apa yang sudah diperoleh dari pertemuan diperoleh dari pertemuan konseling kelompok, perasaan yang dialami selama kegiatan berlangsung, kesan yang diperoleh selama kegiatan kepada peserta didik. Dari penjelasan proses bimbingan kelompok sebanyak 4 kali tersebut, rata-rata pelaksanaan konseling kelompok sudah dilakukan dengan baik dan sesuai prosedur konseling kelompok. Setelah itu pemimpin kelompok mengakhiri proses konseling dan mengucapkan salam, lalu mengajak peserta didik untuk mengucapkan alhamdullilah.

6) Pertemuan keenam

Pada pertemuan keenam ini dilaksanakan pada hari jum'at tanggal 23 september 2016. Peneliti memberikan angket kematangan karir dalam posttest. Posttest diberikan kembali untuk mengetahui seberapa penurunan perubahan perilaku peserta didik setelah diberikan treatment. selain memberikan posttest peneliti juga memberikan penguatan positif terhadap peserta didik agar tidak ragu lagi dalam merencanakan karir masa depan peserta didik tersebut tetap menetap. 
Hasil uji statistik layanan informasi dalam meningkatkan kematangan karir peserta didik. layanan informasi dapat meningkatkan kematangan karir peserta didik dapat dilihat dari perbandingan hasil prettest (sebelum diberikan layanan) dan hasil postest (sesudah pemberian layanan). Sebelum dilakukan perbandingan hasil pretest dan posttest, terlebih dahulu dilakukan uji $t$ untuk mengetahui bahwa layanan informasi dapat meningkatkan kematangan karir peserta didik. Hipotesis yang diajukan dalam penelitian ini adalah:

$\mathrm{H}_{\mathrm{a}}=$ meningkatnya kematangan karir pada peserta didik untuk mengatasi perilaku agresif peserta didik kelas X MAQ Kotabumi Lampung utara tahun pelajaran 2016- 2017

$\mathrm{H}_{\mathrm{o}}=$ tidak meningkatnya kematangan karir pada peserta didik untuk mengatasi perilaku agresif peserta didik kelas X MAQ Kotabumi Lampung utara tahun pelajaran 20162017

Ho: $\mu 1=\mu 0$

Pembahasan penelitian diawali dengan profil kematangan karir peserta didik dilanjutkan dengan menganalisis layanan konseling kelompok. Adapun pembahasan kefektifan layanan konseling kelompok dalam maningkatkan kematngan karir peserta didik adalah sebagai berikut:

Berdasarkan hasil prettest yang telah dilakukan menunjukan bahwakematngan karir peserta didik rata- rata berada pada kategori tinggi dan sedang. Apabila dibiarkan akan mempengaruhi kegiatan belajar peserta didik disekolah. Dalam hal ini dipandang sangat mempengaruhi peserta didik terutama di masa perkembangan yang dilaluinya terutama usia remaja. Hal ini jelas bahwa untuk membentuk pribadi yang mandiri dan bertanggung jawab serta mengoptimalkan potensi yang ada pada diri peserta didik.

Berdasarkan hasil tersebut maka peneliti menggunakan layanan konseling kelompok pada dasarnya adalah layanan konseling perorangan yang dilaksanakn didalam suasana kelompok. Pada pelaksanaan konseling kelompok yang terjadi hubungan yang hangat, permisif, terbuka dan penuh keakraban. Selain itu juga ada pengungkapan dan pemahaman masalah peserta didik, penelusuran sebab- sebab timbulnya masalah, upaya pemecahan masalah, kegiatan evaluasi dan tindak lanjut. Didalam konseling kelompok terdapat dinamika interaksi sosial yang dapat berkembang dengan intensif dalam suasan kelompok. Melalui dinamika interaksi sosial yang terjadi antar anggota kelompok, masalah yangdialami oleh masing-masing individu akan dienteskan. Dinamika interaksi sosial yang secara intensif terjadi dalam suasana kelompok dapat meningkatkan kematangan karir. dengan modifikasi perilaku sebagai tindakan yang bertujuan untuk mengubah perilaku. Modifikasi perilaku daat sebagai usaha menerapakan prinsip-prinsip belajar hasil pada perilaku manusia

Berdasarkan analisis data yang menunjukan adanya perbedaan dari yang tidak memiliki rencana masa depan sampai memiliki rencana masa depan peserta didik setelah dilaksanakan layanna konseling kelompok menjadi lebih baik dari kriteria rendah menjadi tinggi, adapun peningkatan kematangan karir pesert didik dapat diliahat pada indikator.

\section{Simpulan dan Saran}

Berdasarkan hasil penelitian ditunjukan dengan analisis data dan pembahasan maka peneliti dapat menyimpulkan bahwa layanan informasi dengan konseling kelompok di Madrasah Aliyah Qudsiyah Kotabumi lampung utara sangat efektif. Kematangan karir peserta didik dapat meningkat. Meskipun pada awalnya peserta didik masih merasa bingung dalam mengikuti layanan konseling kelompok, namun setelah peneliti menjelaskan tujuan konseling kelompok dan dengan berjalanya penelitian ini peserta didik mulai berantusias dan semangat dalam mengikuti kegiatan konseling kelompok. Setelah diberikan treatment konseling kelompok. Berdasarkan hasil analisis data perhitungan rata-rata skor kematangan karir sebelum mengikuti layanan konseling kelompok adalah rendah dan setelah mengikuti layanan konseling 
kelompok menjadi tinggi. Dari hasil uji t menggunakan program SPSS versi 16 dapat diketahui bahwa dapat rata-rata posttest adalah 73,3dan rata-rata prettest adalah 47,2. Berdasarkan hasil perhitungan pengujian diperoleh $t_{\text {hitung }} 4,063$ padaderajadkebebasan (df) 9 kemudiandibandingkandengan $t_{\text {tabel }} 0,05=2,262$, ketentuan $t_{\text {hitung }}$ lebih besar dari $t_{\text {tabel }}(4,063 \geq$ 2,262). Ini menunjukan bahwa Ho ditolak dan Ha diterima, selain itu dapat nilai rata- rata, maka peningkatan kematangan karir peserta didik setelah diberikan layanan lebih tinggi dibandingkan sebelum diberikan layanan. Dengan demikian kematangan karir peserta didik terdapat perubahan setelah diberikan layanan konseling kelompok. Maka 83 disimpulkan bahwa terdapat efek layanan konseling kelompok dalam meningkatkan kematangan karir peserta didik kelas X Di Madrasah Aliyah Qudsiyah Lampung Utara tahun pelajaran 2016/2017. Kesimpulan dalam penelitian ini yaitu kematangan karir rendah dapat ditingkatkan melalui konseling kelompok pada peserta didik. hal ini ditunjukkan dari perubahan perilaku peserta didik dalam setiap pertemuan pada kegiatan konseling kelompok. juga perilaku peserta didik dalam kegiatan sehari-hari.

Dari kesimpulan diatas, maka peneliti memberi saran-saran sebagai berikut: untuk guru bimbingan konseling agardalam proses pendekatan konseling kelompok perlu ditingkatkan terutama dalam menerapkan metode dan teknik dalam terapi agar dapat memperoleh hasil yang lebih baik dan sempurna. Kepada pihak sekolah diharapkan dapat membantu mengembangkan program bimbingan dan konseling sebab program tersebut sangat berguna untuk mengatasi masalah peserta didik. Untuk peserta didik diharapkan agar lebih aktif dalam melakukan konsultasi ketika menghadapi masalah-masalah yang menghambat proses pemelajaran. Bagi peneliti selanjutnya diharapkan dapat dijadikan sumbangan pikiran bagi peningkatan kualitas dan konpetensi pribadi guru bimbingan dan konseling untuk melaksanakan tugas dan tanggung jawab dengan baik.

\section{Daftar Pustaka}

Al-Quran Terjemahan. Penyelenggara Penerjemah Al-Quran.

Anifa Nisrina Ayuni, Kematangan Karir Siswa Kelas Xl Ditinjau Dari Tingkat Pendidikan Orang Tua Dan Keadaan Ekonomi Keluarga Di Sma Negeri 1 Pakem Tahun Ajaran 2014/2015 (Skripsi Program Studi Bimbingan Dan Konseling Jurusan Psikologi Pendidikan Dan Bimbingan Fakultas Pendidikan Universitas Hegeri Yogyakarta) 2015

Arikunto, Suharsini, Prosedure Penelitian Jakarta, Rineka Cipta. 2010

Dewa Ketut Sukardi, MBA,MM. Pengantar Pelaksanaan Program Bimbingan Dan Konseling Di Sekolah, Pt Rineka Cipta, Jakarta, 2008

Gani, A. Ruslan, Bimbingan Karir, Angkasa, Bandung Cet2. 2010

Hendrik, Model Bimbingan Kelompok Berbasis Nilai-Nilai Entrepreneurship Untuk Meningkatkan Kematangan Karir Siswa,(Jurnal Penelitian Tindakan Kelas Vol.16, No 3, Januari 2015 IKIP PGRI Pontianak Kalimantan Barat, Hlm 26.(23 Oktober 2016)

M. Ramli, Pengaruh Layanan Informasi Terhadap Kematangan Karir Siswa Sma Negeri 1 Kwandang Kabupaten Gorontalo Utara, Jurusan Bimbingan Dan Konseling Universitas Negeri Gorontalo, Gorontalo.

Novalia, Muhamad Syazali, Olah Data Penelitian Pendidikan, Bandar Lampung, 2014

Nurul Hidayah, Model Konseling Trait And Factor Terhadap Perencanaan Karir Pada Peserta Didik Kelas Vll Sekolah Manangah Pertama Negeri 28 Bandar Lampung Tahun Pelajaran 2013, Skripsi, (Bandar Lampung: Iain Raden Intan Lampung, 2014),

Prayitno Dan Amti, Erman, Dasar-Dasar Bimbingan dan Konseling. Jakarta, Pt. Rineka Cipta.2008 
Purwati, Cicih. Meningkatkan Minat Studi Lanjut Ke Smk Melalui Layanan Informasi Karir Peserta Didik Kelas VIII SMP 2 Salem, Skripsi, Semarang, Universitas Negeri Semarang.

Rahma, Ulifah, Bimbingan Karir Peserta Didik, Malang : UIN:MALIKI Pres. 2010

Raja Grafindo Persada.2008

Rusman Tedi, Aplikasi Statistik Penelitian dengan SPSS edisi 4,Bandar Lampung, 2013

Sadiana, Khuria. Pengaruh Penggunaan Konseling Kelompok Rasional Emotif Terapi Dalam Meningkatkan Konsep Diri Positif Pada Peserta Didik Kelas X Do Sekolah Menengah Kejuruan Yayasan Pendidikan Krisna Bandar Lampung Tahun Ajaran 2013/2014. Skripsi,( Bandar Lampung), 2014

Sugiyono,Metode Penelitian Manajemen, Bandung, Penerbit Alfabeta.2013. Surakarta CV.ITA. 2014

Tohirin, Bimbingan Dan Konseling Di Sekolah Dan Madrasah, Jakarta, Pt. Undang-Undang Dasar Republik Indonesi, Pasal 27 (2), Surakarta CV.IT, Wagilto, Bimo.Bimbingan Dan Konseling, Yogyakarta: ANDI,2010 